\title{
Runestone N KJ49B Fuglset
}

\author{
James E. Knirk (University of Oslo)
}

\begin{abstract}
The stone inscribed with older runes from Fuglset in Molde municipality, western Norway, was found in 1939 and published by Magnus Olsen in 1941. It is mentioned in a footnote in Krause and Jankuhn's corpus edition (1966) and at present forms an entry in the Scandinavian Runic Text Database and in the Kiel older runic database ("Kieler Runendatei"). Since the mid-1980s, however, the head of the Runic Archives in Oslo had strongly suspected it to be modern. Thus it came to be included in the corpus of an Oslo thesis from 2001 on Norwegian post-Reformation runic inscriptions. More recently it came to the attention of the Runic Archives that the finder had in 1997 sent a letter to the University Museum in Trondheim in which he owned up to having himself carved the runes and set the record straight.
\end{abstract}

Keywords: N KJ49B Fuglset, runic hoax, modern runic inscription

Tn October 1939, while digging a ditch along the driveway of his family's 1 small farm near the outskirts of Molde, fourteen-year-old Alfred Fuglset found, buried under gravel at an estimated depth of $50 \mathrm{~cm}$, a small, flat, triangular stone with maximum measurements $11.9 \times 8.9 \times 2.2 \mathrm{~cm}$. On one of the flat surfaces it had seven older runes set out in two parallel lines, three in the top line and four below. The artefact was sent to the museum of the Royal Norwegian Society of Sciences and Letters in Trondheim (now the University Museum, Norwegian University of Science and Technology [Vitenskapsmuseet, NTNU]), where it was given inventory no. T 15806 in the archaeological collection (cf. Petersen 1940, 22 f.). Theodor Petersen suggested in his catalogue entry that the stone might possibly have been a sinker on a fishing net or a weight for a loom; he also mentioned that the runes had been retraced ("gått etter") with a knife.

About two years after the Fuglset stone was found, Magnus Olsen (1941, 7-16) published its runic inscription. Following a lengthy presentation of

Knirk, James. "Runestone N KJ49B Fuglset."

Futhark: International fournal of Runic Studies 11 (2020, publ. 2021): 177-81.

DOI: $10.33063 /$ diva-438143 
the circumstances of the find and a thorough description of the object itself, he turned to the question of its authenticity in which he relied in part on discussions with Petersen and a geologist (pp. 9 f.). In a letter to Olsen, Petersen had assured him that there was no reason to doubt the authenticity of the inscription. Olsen, however, pointed out that the carving technique varied greatly from that of other inscriptions with older runes, and that there was also variation between two sets of the characters on the stone itself, five of them having sharp, clear lines, but one or two with faint contours suggesting they had been "rubbed in" ("inngnedet"). In addition, Olsen believed that he could discern similar faint contours under some of the sharp lines of the other five characters. By examining the carvings through a microscope, Victor Moritz Goldschmidt, the geologist mentioned above, was able to determine that the sharp, clear lines were from "recent times" ("ny tid"), a conclusion he reached due mainly to the fact that patches of iron oxide on the surface of the stone were discontinuous where they had been cut through by the sharp lines. Magnus Olsen considered the most reasonable explanation for this state of affairs to be that genuine older runes (i.e. the contours that appeared to have been rubbed in) had been "freshened up" in recent times.

This assumption was confirmed in a letter from Alfred Fuglset to Petersen, but the finder's first statement in that letter is revealing (quoted in Olsen 1941, 10): “Når De spør mig om jeg har 'gått efter' og risset i de før skrevne bokstaver, så må jeg nok innrømme at jeg har gjort det” (You ask me if I "retraced" and scratched over the existing letters, and I must indeed admit that I did so). This indicates shoddy detective work on the part of Petersen: One does not provide a person suspected of having done something underhand, something that created an anomaly, with a suggestion as to what the person's actions may have been - and then simply accept the suspect's subsequent admission that the proffered explanation is indeed correct. The boy went on to explain that he was interested in the find and that he, not unreasonably, washed the stone and then used a knife to clean the characters. After quoting the finder, Magnus Olsen went on to state that nobody having read this open and honestly formulated letter could nurture any suspicion that the weakly carved runic contours might have been made in 1939. He thus deemed the inscription genuine, but considered the runes to be so damaged by the knife-cleaning exercise in 1939, that the reading had to be considered uncertain and thus also any interpretation of the message. He thereupon proposed that the original reading was (p. 11): $\uparrow \mathcal{R}|\mathrm{P}| \uparrow M$, tor | wite, although the reading of the first two characters, both with weakly carved 
contours, was somewhat unsure. He suggested (pp. 13 f.) that these runes might be interpreted as representing a compound word normalised as " tór-viti (< *toðr-viti), which he translated as 'den som trygger avkommet, tilveksten, utbyttet' (see the English translation in the citation of the Kiel older runic database below). Since, as postulated by Petersen, the stone could have been a sinker on a fishing net, Olsen went on to suggest a possible, more precise translation: 'den som trygger havets yngel, fiskestimene, fiskefangsten' (the one who secures the ocean's fry [young fish], the schools of fish, the catch). He dated the inscription to c. 700 or soon thereafter (p. 14) but closed by admitting how much uncertainty surrounded his philological endeavour.

This reading and the suggested interpretation were presented concisely in a footnote to the N KJ49 Førde sinker in Krause and Jankuhn's corpus edition of the older runic inscriptions $(1966,110)$. The Fuglset inscription was not included in the edition proper due to the uncertainty of the reading stemming from the touching up of the runes by the finder: "Wegen der Nachritzung durch den Finder ist keine sichere Lesung mehr möglich." From the footnote, however, the inscription made its way into the Scandinavian Runic Text Database, where the English translation is 'the one who ensures the livelihood [not a correct translation of Olsen's "avkommet"], growth, yield'. The Fuglset inscription is also included in the Kiel older runic database ("Kieler Runendatei") and the text translated: 'der Nachkommen, Zuwachs/Nachwuchs, Gewinn/Ertrag/Ausbeute sichert' or in English: 'who ensures offspring, growth, profit/yield'.

In 1985, in preparation for a lecture concerning "censorship" in runic research to be held at the Second International Symposium on Runes and Runic Inscriptions in Sigtuna that year (not published in the proceedings), the head of the Runic Archives went through all inscriptions registered as likely post-Reformation products as well as others registered as suspicious or possibly post-medieval. "Censorship" in this connection related to the fact that registration centres such as the Runic Archives generally do not publish or otherwise make known to the public - not even to colleagues - obvious or suspected hoaxes or indeed any obviously post-Reformation inscription for whatever purpose it may have been made. (Inscriptions from Norway of this kind were, however, published yearly in the "new finds" articles in Nytt om runer: Meldingsblad om runeforskning for the nineteen years of its existence.) During the 1985 inspection of the material, the inscription from Fuglset was deemed highly suspect and its folder transferred physically from the files of older runic inscriptions to those of uncertain and post-Reformation ones. As such, it was included, with some 
hesitation, in the corpus of K. Jonas Nordby's 2001 Master's thesis on the post-Reformation runic inscriptions of Norway (p. 168, cf. p. 21).

Unbeknown to the Runic Archives, the Fuglset inscription had, a few years before the completion of Nordby's thesis, been unmasked as a hoax. On 12 February 1997 Alfred Fuglset wrote a letter addressed to the "university collection of antiquities" in Trondheim (journal no. 97/227-1, 24 Feb. 1997). There he explained that the museum had in its collection a palm-of-the-hand-sized stone from Fuglset with runes engraved. He explained that it was his father, Johannes, who had found the stone some time before the war, perhaps around 1936-37. His recollection was thus not entirely correct, so other minor details may likewise not be wholly trustworthy. There is, however, no reason to doubt his admission of guilt:

Jeg må her komme med en bekjennelse. Det var meg som ung gutt i 12-13 årsalderen som selv risset inn disse runetegn, for å drive spøk med mine søsken. Denne stenen er altså ikke noe oldtidsminne. Jeg er idag en eldre mann og ønsker ikke å legge etter meg et falsum.

(Here I have to make a confession. It was I, as a young boy of 12-13 years, who carved these runic signs myself, in order to play a prank on my siblings. This stone is thus not an ancient artefact. I am today an elderly man and do not wish to leave a forgery behind me.)

Fuglset concluded by stating that he hoped there would not be any publicity surrounding his admission. The short notice presented here should not be considered "publicity"; it represents rather the necessary dissemination of truthful and important information that should be made available to those who work with runes and runic inscriptions, e.g., the readers of Futhark.

Alfred Fuglset was an honest man who as a child had played an innocent prank, perhaps on his siblings, but the joke had unintended consequences. It is to his credit that, toward the close of his life at age seventy-one, he took the step needed to correct the misunderstanding caused by his childhood actions. Alfred Fuglset died some six years later, on 26 August 2003.

It is to be hoped that this short notice will lead to the removal of N KJ49B Fuglset from the Scandinavian Runic Text Database in the next, revised version that appears. It is also to be hoped that the inscription will be moved from the list of genuine older runic inscriptions presented in the Kiel older runic database ("Kieler Runendatei") to its separate list of suspected falsifications ("Fälschungsverdächtige Inschriften"). 


\section{Bibliography}

"Kieler Runendatei" = Kiel older runic database, i.e., Runenprojekt Kiel: Sprachwissenschaftliche Datenbank der Runeninschriften im älteren Futhark. http:// www.runenprojekt.uni-kiel.de/abfragen

Krause, Wolfgang, and Herbert Jankuhn. 1966. Die Runeninschriften im älteren Futhark. 2 vols. Abhandlungen der Akademie der Wissenschaften in Göttingen, philologisch-historische Klasse, 3rd ser., 66. Göttingen.

$\mathrm{N} \mathrm{KJ}+$ no. = inscription from Norway with older runes published in Krause and Jankuhn 1966; signum according to the Scandinavian Runic Text Database.

Nordby, K. Jonas. 2001. "Etterreformatoriske runeinnskrifter i Norge: Opphav og tradisjon." Master's thesis (unpublished), Germanic Department, University of Oslo.

Nytt om runer: Meldingsblad om runeforskning. Ed. James E. Knirk. 19 issues. 1986-2004 (last issue published 2006).

Olsen, Magnus. 1941. To nye fund av urnordiske runer (Hammeren B og Fuglset). Det Kongelige Norske Videnskabers Selskab, Skrifter, 1940-41, no. 1 (16 pp.). Trondheim.

Petersen, Theodor. 1940. Det Kongelige Norske Videnskabers Selskab, Museet: Oldsaksamlingens tilvekst 1939. Trondheim.

Scandinavian Runic Text Database (Samnordisk runtextdatabas). Department of Scandinavian Languages, Uppsala University. http://www.nordiska.uu.se/ forskn/samnord.htm 
